Ivana Krišto, Cvetan Kovač and Ana Šijaković

\title{
Covid-19: the most common occupational disease in 2020 in the Republic of Croatia*
}

\begin{abstract}
The global pandemic of the SARS-CoV-2 virus and the consequent illness of healthcare workers from Covid-19 are largely responsible for the increase in the reported number of occupational diseases in the healthcare and social care sector in 2020 in the Republic of Croatia. It is important to note that Covid-19 was the most common occupational disease in the field in 2020. The health sector is first in line as a result of workers' role in the diagnosis and treatment of those suffering from the disease and it could therefore be expected that the largest number of sick workers would be in this sector. After recovery (approximately 15 days), and assuming there are no complications, sick workers return to work but as we do not yet know the extent of the effects of this disease, it is not possible to predict whether there will be subsequent absences due to complications from Covid-19. This article reports the trends in the notification of occupational diseases under Croatia's involved reporting system and categorises workers experiencing occupational diseases by type of disease, sector of activity and geographical location.
\end{abstract}

Keywords: Covid-19, occupational disease, reporting system and procedure, healthcare, social welfare

Introduction

The procedure for determining and recognising occupational diseases in Croatia is carried out on the basis of the Occupational Diseases List Act (OG 162/98) and the Amendments to the Occupational Diseases List Act (OG 107/07); in line with the Compulsory Health Insurance Act (OG 80/13, 137/13 and 98/19); and subject to the Regulation on the rights, conditions and manner of exercising compulsory health insurance rights in the event of an injury at work or an occupational disease (OG $75 / 14,154 / 14,79 / 15,139 / 15,105 / 16,40 / 17,66 / 17,109 / 17,132 / 17,119 / 18,41 / 19$, $22 / 20$ and $39 / 20$ ).

According to the provisions of these legal regulations, in a case where an occupational disease is suspected, a formal Report on an Occupational Disease is filled out. In the process of establishing the facts for the purpose of recognising an occupational

* This article provides an overview of some of the results presented in the Register of Occupational Diseases for 2020, prepared by the Occupational Medicine Service (SMR) of the Croatian Institute of Public Health (HZJZ) and publicly available on the HZJZ website (http://www.hzzzsr.hr/wp-content/uploads/2021/05/Registar-profesionalnih-bolesti-za-2020.p df). 
disease, the opinion of a competent doctor specialised in occupational medicine must be obtained, in addition to that of Službi za medicinu rada (SMR; the Occupational Medicine Service) of Hrvatski zavod za javno zdravstvo (HZJZ; the Croatian Institute of Public Health). This procedure is initiated by submitting the appropriate form to the regional office of Hrvatski zavod za zdravtstveno osigranje (HZZO; the Croatian Institute for Health Insurance), either according to the place of residence of the insured person or to the HZZO regional office in the area where the employer is registered. The form is submitted in five copies and, in addition to the employer, it may also be submitted by the selected doctor of general (or family) medicine of the insured person or by the insured person themself by submitting a written request for the establishment of an occupational disease. The following must be attached to the report, or to the written request:

1. a finding or confirmation of a positive SARS-CoV-2 test (may be stated in the findings of a virologist or epidemiologist)

2. medical documentation of the disease (e.g. the findings of a virologist or a discharge letter)

3. the findings and opinion of the epidemiologist (source of infection, movements, patients in the family)

4. the findings and opinion of the competent occupational medicine specialist on the existence of the occupational disease (a doctor of occupational medicine selected by the employer)

5. a copy of the health card of the insured worker from the family doctor with a list of all the diseases from which the worker suffers

6. from the employer:

a) a detailed description of the workplace and the work tasks performed by the worker in the 14 days prior to the development of symptoms (or a positive test)

b) a statement on the presence of the insured person in the workplace in the 14 days prior to the development of symptoms (or a positive test)

7. a statement by the insured person (what he or she did; when he or she became infected; whether he or she had symptoms and, if so, which ones).

In accordance with Article 49(2) of the compulsory health insurance regulation, the Institute is obliged in the process of determining an occupational disease to seek expert medical opinion from the Institute of Public Health in relation to the circumstances in question. Occupational medical expertise is offered in accordance with Article 2 of the current List of Occupational Diseases Act. The accepted design of treatment programmes in occupational medicine encompasses a summary of the work history and a presentation of the relationship between the disease and the level of occupational exposure; a determination of the intensity and duration of exposure related to the workplace; and the overall clinical picture with outcomes which are related to the methods of diagnosis.

Following this, the justification for filing a report of an occupational disease exists where there are appropriate arguments and documentation or evidence which meet the above conditions on the basis of the regulations. 
A positive professional medical opinion from the Occupational Medicine Service of the Institute of Public Health results in compulsory health insurance rights being recorded as of the date the disease was determined as an occupational disease.

The task of the SMR's occupational medicine specialist is to confirm or eliminate the occupational source of the disease. Where such a cause is confirmed, all data relevant to the disease and the level of occupational exposure are entered in the Register of Occupational Diseases maintained by HZJZ in harmony with the Croatian legislation and with EU recommendations in the field of the statistical monitoring of parameters related to health and safety at work.

Administrative data on the number of people in employment are based on data from statistical analyses conducted by the Central Office of Statistics according to its own methodology and published within its annual Statistical Yearbook.

\section{Register of Occupational Diseases}

SMR maintains the Register as one of the important public interest activities that HZJZ continuously carries out on behalf of the Ministry of Health. The Register monitors recognised occupational diseases at state level and thus provides a basis for preventive actions in the field of the protection of the health of the working population.

The Register analyses the number and trends of occupational diseases in Croatia; the characteristics of sick workers (age, gender, length of service, education); and the economic activities and occupations in which occupational diseases are found. It also analyses the harmful conditions and types of damage caused by an occupational disease.

\section{List of occupational diseases}

The Compulsory Health Insurance Act (OG 80/13, 137/13 and 98/19) defines occupational diseases as those which result from a longer direct impact of aspects of the work process and working conditions in certain jobs.

Likewise the Occupational Diseases List Act (OG 162/98) and the Act on Amendments to the Occupational Diseases List Act (OG 107/07) define an occupational disease that is known to be the result of hazardous effects related to the work process and/or the working environment; and where the intensity of the damage and the duration of exposure to that damage is at a level known to be hazardous to health.

The list of occupational diseases and jobs in which these diseases occur, as well as the conditions under which they are considered occupational, is binding and is an integral part of the Act (OG 107/07).

The diagnostic procedure includes:

1. work history and a proof of the connection between illness and workplace exposure

2. the clinical picture with the appearance of impaired function and/or the structural form of organs or organ systems that are known to be susceptible to certain occupational hazards

3. positive findings of the diagnostic methods that can objectify this damage. 
The presence of damage is determined as a result of:

1. risk assessment, or in another way that enables the presence of damage to be determined with certainty

2. determining both the intensity (by measuring, obtaining direct insight into working conditions or in another way that enables the intensity of the damage to be determined with certainty) and the duration of exposure.

Register of Occupational Diseases for 2020 in the Republic of Croatia

In 2020, the number of instances of occupational diseases almost doubled in comparison with 2019 (see Figure 1). In the period covering the last ten years the total number of instances of occupational disease firstly gradually decreased, from 488 in 2011 to 113 in 2015 , before rising and then falling back again until 2020's increase (to 264).

Figure 1 - Number of recognised occupational diseases in Croatia, 2011-2020

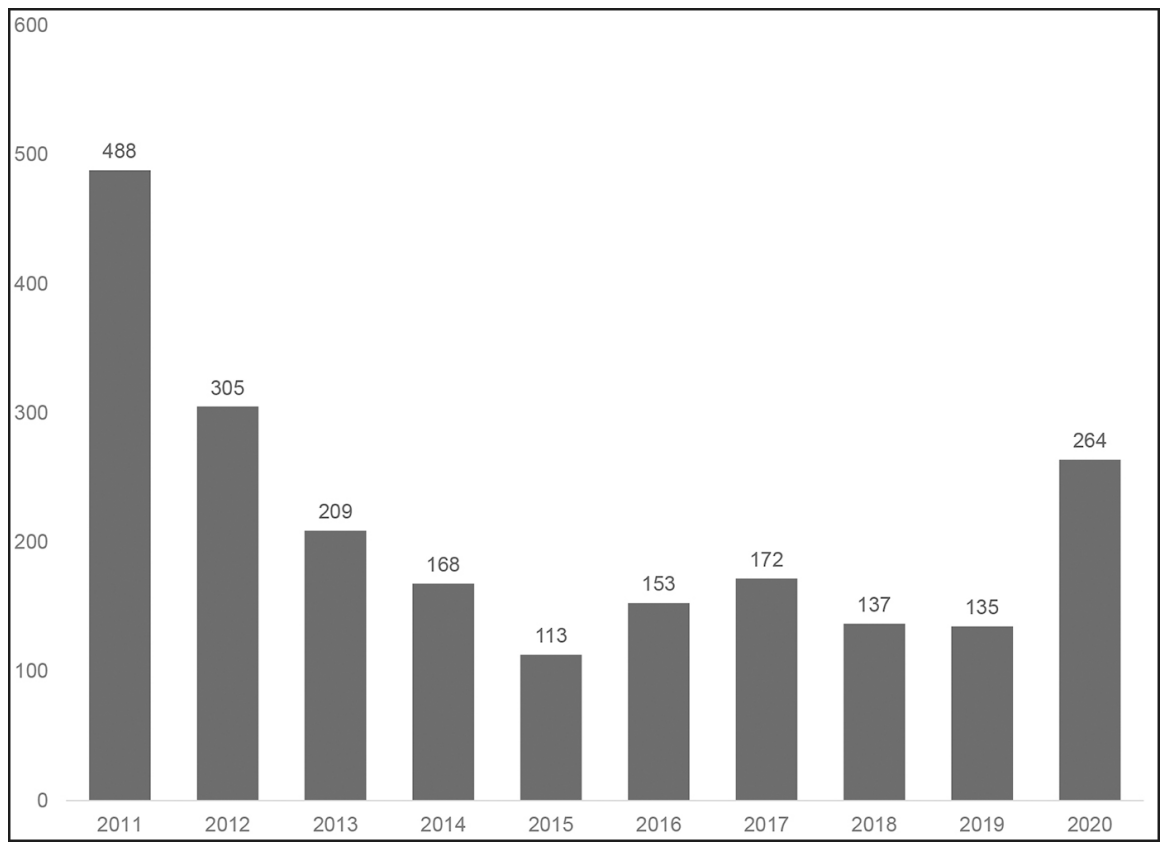

Source: Register of Occupational Diseases for 2020, HZJZ

The reasons for such dynamics should primarily be sought in the structure of registered diagnoses that have established an occupational source: namely this number includes all cases of occupational disease that are recognised in the health insurance system, meaning that occupational diseases that have occurred as a result of exposure to asbestos fibre are also included. According to a special regulation, this group of diseases is monitored in a register of workers suffering from occupational diseases 
caused by asbestos but, due to their occupational origin, they are also registered in the Register of Occupational Diseases, thus significantly affecting the total number of occupational diseases within each calendar year. During 2011 and 2012, there was a high number of requests for determining the occupational origins of diseases caused by exposure to asbestos fibre which subsequently caused a large increase in the total number of cases of occupational disease, far higher than in other calendar periods. However, there has been a gradual decline in the number of cases caused by asbestos since then, which has direct implications for the decline in the number of cases of occupational disease overall.

If we look at cases of occupational disease but exclude those caused by asbestos, it is evident that their number is significantly lower: in the total number of cases of occupational diseases between 2011 and 2017, they are represented in less than onehalf while, in 2018, they rose to more than one-half (see Figure 2). The share of cases not caused by asbestos has been steadily rising: 23 per cent in 2012; in 2013, 35 per cent; in 2014 and 2015, 37 per cent; and in 2016, 36 per cent. In 2017, it jumped to 48 per cent and in 2018 to 58 per cent before falling back in 2019 to 44 per cent. Excluding cases caused by exposure to asbestos fibre, we may conclude that the number of remaining cases of occupational disease in the period from 2013 to 2015 or 2016 declined, before seeing a significant increase in 2017 and 2018. In 2019, the number of cases decreased again.

In 2020, there was a major increase in the share of diseases not caused by asbestos to 84 per cent of the total. The current pandemic caused by the SARS-CoV-2 virus, which started in early 2020 , has greatly contributed to this. 
Figure 2 - Share of cases of occupational disease caused by asbestos and other occupational diseases in Croatia, 2011-2020

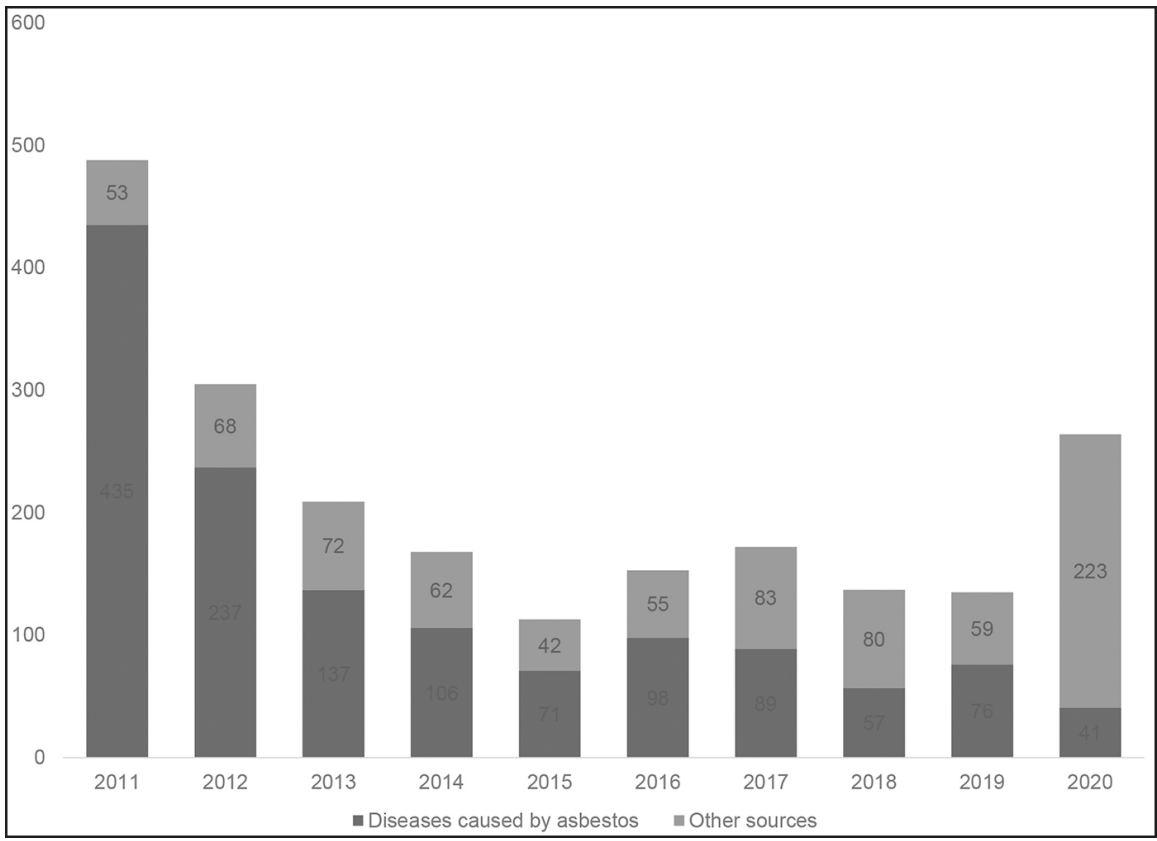

Source: Register of Occupational Diseases for 2020, HZJZ

Types of occupational diseases in Croatia in 2020

The frequency and type of occupational diseases in 2020, according to the Law on Amendments to the Law on the List of Occupational Diseases, is shown in Table 1.

Table 1 - Extract from the number and types of occupational diseases (excl. asbestos) in Croatia in 2020

\begin{tabular}{|l|c|c|c|c|c|c|c|c|c|}
\hline \multirow{2}{*}{$\begin{array}{l}\text { National Classification of } \\
\text { Activities }\end{array}$} & \multicolumn{6}{|c|}{ Label according to the Law on the List of Occupational Diseases (OG } \\
\cline { 2 - 9 } & $\mathbf{3 7 . 1}$ & $\mathbf{3 8}$ & $\mathbf{4 1}$ & $\mathbf{4 3}$ & $\mathbf{4 4}$ & $\mathbf{4 5}$ & $\mathbf{4 7}$ & $\mathbf{4 8}$ & Tot. \\
\hline $\begin{array}{l}\text { Agriculture, forestry and } \\
\text { fishing }\end{array}$ & 4 & & & & & & & & 4 \\
\hline Mining and quarrying & & & & & & & & & 0 \\
\hline Manufacturing & & & 5 & & 1 & 6 & 1 & 2 & 16 \\
\hline $\begin{array}{l}\text { Electricity, gas, steam and air } \\
\text { conditioning }\end{array}$ & & & & & & & & & 0 \\
\hline
\end{tabular}


Covid-19: the most common occupational disease in 2020 in the Republic of Croatia

\begin{tabular}{|c|c|c|c|c|c|c|c|c|c|}
\hline \multirow[t]{2}{*}{$\begin{array}{l}\text { National Classification of } \\
\text { Activities }\end{array}$} & \multicolumn{9}{|c|}{$\begin{array}{l}\text { Label according to the Law on the List of Occupational Diseases (OG } \\
\qquad 107 / 07)\end{array}$} \\
\hline & 37.1 & 38 & 41 & 43 & 44 & 45 & 47 & 48 & Tot. \\
\hline $\begin{array}{l}\text { Water supply, wastewater } \\
\text { disposal, waste management } \\
\text { and remediation activities }\end{array}$ & & & 1 & & & & & & 1 \\
\hline Construction & & & & & & & & & 0 \\
\hline $\begin{array}{l}\text { Wholesale and retail trade; } \\
\text { repair of motor vehicles and } \\
\text { motorcycles }\end{array}$ & & & 1 & & & 1 & 1 & & 3 \\
\hline Transport and storage & & & & & & & & & 0 \\
\hline $\begin{array}{l}\text { Accommodation and food } \\
\text { service activities }\end{array}$ & & & & & & & & & 0 \\
\hline $\begin{array}{l}\text { Information and } \\
\text { communications }\end{array}$ & & & 1 & & & & & & 1 \\
\hline $\begin{array}{l}\text { Financial and insurance } \\
\text { activities }\end{array}$ & & & & & & 3 & & & 3 \\
\hline Real estate business & & & 1 & & & & & & 1 \\
\hline $\begin{array}{l}\text { Professional, scientific and } \\
\text { technical activities }\end{array}$ & & & & & & & & & 0 \\
\hline $\begin{array}{l}\text { Administrative and support } \\
\text { service activities }\end{array}$ & & & & & & & & & 0 \\
\hline $\begin{array}{l}\text { Public administration and } \\
\text { defence; compulsory social } \\
\text { insurance }\end{array}$ & & & 8 & 8 & & 15 & & & 24 \\
\hline Education & & & & 1 & & & & & 1 \\
\hline $\begin{array}{l}\text { Health and social welfare } \\
\text { activities }\end{array}$ & & 1 & 1 & & & 158 & & & 160 \\
\hline $\begin{array}{l}\text { Arts, entertainment and } \\
\text { recreation }\end{array}$ & & & 2 & & & & & & 2 \\
\hline Other service activities & & & & & & 1 & & & 1 \\
\hline $\begin{array}{l}\text { Activities of the household as } \\
\text { an employer; households that } \\
\text { produce different goods and } \\
\text { perform different services for } \\
\text { their own needs }\end{array}$ & & & & & & & & & 0 \\
\hline $\begin{array}{l}\text { Activities outside territorial } \\
\text { organisations and bodies }\end{array}$ & & & & & & & & & 0 \\
\hline Total & 4 & 1 & 20 & 2 & 1 & 190 & 2 & 2 & 223 \\
\hline
\end{tabular}

Source: Register of Occupational Diseases 2020, HZJZ

Key: 
37.1 Diseases caused by vibration transmitted to the hands (damage to peripheral blood vessels and nerves, bones, joints, tendons and surrounding tissues)

38 Diseases caused by ionizing radiation

41 Overexertion syndromes caused by cumulative trauma (repetitive movements, application of force, non-physiological position, vibration, pressure)

44 Infectious or parasitic diseases transmitted to humans from animals or animal remains

45 Infectious or parasitic diseases caused by work in industries where an increased risk of infection has been demonstrated

47 Skin diseases caused by substances that have been scientifically confirmed to have an allergic or irritant effect, not mentioned in other headings

\section{Geographical distribution of occupational diseases in Croatia}

The geographical distribution of the type and number of cases of occupational disease may be analysed by monitoring the number of patients by individual cities or counties from which applications to the Register of Occupational Diseases arrive. In 2020 , reports of cases of occupational disease were received from almost all parts of the Republic of Croatia; Table 2 shows the distribution of the received data. Differences in the number of cases in each county may be due to the different representation of individual economic activities which, given the wide range of work processes, also carry different occupational risks.

City of Zagreb and Split-Dalmatia county, both with 51 cases of recognised occupational diseases (excluding asbestos), differ widely in the make-up of such cases. Large numbers might be expected in City of Zagreb and Split-Dalmatia given the large number of employees in both places and given that Zagreb is the administrative centre of the country; furthermore, Split-Dalmatia is the largest county in the country while Split itself is the second largest city in terms of population. In City of Zagreb, a large share of employees work in service and trade occupations so the presence of a large number of cases of disease caused by overexertion was expected; the number increasing from five in 2016 to eleven in 2017, nine in 2018 and twelve in 2019.

What is most significant for 2020 across the country as a whole is the number of cases of infectious or parasitic disease caused by work in industries where there is an increased risk of infection, increasing from six in 2019 to 190. The reasons for such an increase are found in the current pandemic, with the notification of Covid-19 as an occupational disease increasing the number of reports and, consequently, the number of cases of recognised occupational diseases.

\section{Table 2 - Distribution of cases of occupational diseases in 2020 by county}

\begin{tabular}{|l|r|r|r|r|r|r|r|r|r|}
\hline \multirow{2}{*}{ County } & \multicolumn{7}{|c|}{ Label according to the Law on the List of Occupational Diseases (OG } \\
& $\mathbf{3 7 . 1}$ & $\mathbf{3 8}$ & $\mathbf{4 1}$ & $\mathbf{4 3}$ & $\mathbf{4 4}$ & $\mathbf{4 5}$ & $\mathbf{4 7}$ & $\mathbf{4 8}$ & Tot. \\
\hline & & & & & & 1 & & & $\mathbf{1}$ \\
\hline Zagreb County & & & & & & 7 & & 1 & $\mathbf{8}$ \\
\hline Krapina-Zagorje & & & & & & 12 & & & $\mathbf{1 2}$ \\
\hline Sisak-Moslavina & & & & & & & & & \\
\hline
\end{tabular}




\begin{tabular}{|c|c|c|c|c|c|c|c|c|c|}
\hline \multirow[t]{2}{*}{ County } & \multicolumn{9}{|c|}{$\begin{array}{l}\text { Label according to the Law on the List of Occupational Diseases (OG } \\
\qquad 107 / 07)\end{array}$} \\
\hline & 37.1 & 38 & 41 & 43 & 44 & 45 & 47 & 48 & Tot. \\
\hline Karlovac & & & & & & 2 & & & 2 \\
\hline Varaždin & & & 2 & & & 1 & & & 3 \\
\hline Koprivnica-Križevci & & & & & & 0 & & & $\mathbf{0}$ \\
\hline Bjelovar-Bilogora & & & & & & 2 & & 1 & 2 \\
\hline Primorje-Gorski Kotar & & & 1 & & & 2 & & & 4 \\
\hline Lika-Senj & 1 & & & & & 0 & & & 1 \\
\hline Virovitica-Podravina & & & 2 & & & 0 & & & 2 \\
\hline Požega-Slavonia & & & 1 & & & 19 & & & 20 \\
\hline Brod-Posavina & & & 1 & & & 2 & & & 2 \\
\hline Zadar & & 1 & 1 & & & 15 & & & 17 \\
\hline Osijek-Baranja & & & & & & 27 & & & 27 \\
\hline Šibenik-Knin & & & & & & 3 & & & 4 \\
\hline Vukovar-Srijem & 1 & & 1 & & & 1 & & & 2 \\
\hline Split-Dalmatia & & & 1 & 1 & & 50 & & & 51 \\
\hline Istria & 1 & & & & & 7 & 1 & & 9 \\
\hline Dubrovnik-Neretva & & & 1 & & & 1 & & & 2 \\
\hline Međimurje & & & 1 & & & 2 & & & 3 \\
\hline City of Zagreb & 1 & & 10 & & 1 & 36 & & & 51 \\
\hline Total & 4 & 1 & 20 & 1 & 1 & 190 & 1 & & 223 \\
\hline
\end{tabular}

Key and source - as for Table 1 .

Number of cases of occupational disease by activity and rate per 100000 employees

The number of cases of occupational disease in 2020 differed significantly across individual economic activities, classified according to the National Classification of Activities and shown in Table 3. The number of cases (i.e. the rate) per $100000 \mathrm{em}-$ ployees in each activity ranged (in classifications where there was a case) from 1.32 to 128.00 , with a mean value of 13.39 (median 5.55).

The largest number of cases of occupational disease arises in healthcare and social welfare (160), and the highest rate is found in this activity (128.00). Public administration and defence and compulsory social insurance follow (24) albeit that, expressed in terms of the rate per 100000 employees (19.67), this area of activity is in 
third place with real estate business ahead of it in second with a rate of 33.33. In terms of the rate, these are followed by financial and insurance activities; arts, entertainment and recreation; education; manufacturing; and agriculture, forestry and fishing activities.

Table 3 - Number of cases of occupational disease (excl. those caused by asbestos) in 2020 by economic activity and rate/100 000 employees

\begin{tabular}{|c|c|c|}
\hline National Classification of Activities & No. & $\begin{array}{l}\text { Rate } / 100000 \\
\text { employees }\end{array}$ \\
\hline Agriculture, forestry and fishing & 4 & 3.70 \\
\hline Mining and quarrying & 0 & 0.00 \\
\hline Manufacturing & 16 & 5.42 \\
\hline Electricity, gas, steam and air conditioning & 0 & 0.00 \\
\hline $\begin{array}{l}\text { Water supply, wastewater disposal, waste management and remediation } \\
\text { activities }\end{array}$ & 1 & 3.33 \\
\hline Construction & 0 & 0.00 \\
\hline Wholesale and retail trade; repair of motor vehicles and motorcycles & 3 & 1.32 \\
\hline Transport and storage & 0 & 0.00 \\
\hline Accommodation and food service activities & 0 & 0.00 \\
\hline Information and communications & 1 & 1.72 \\
\hline Financial and insurance activities & 3 & 7.14 \\
\hline Real estate business & 1 & 33.33 \\
\hline Professional, scientific and technical activities & 0 & 0.00 \\
\hline Administrative and support service activities & 0 & 0.00 \\
\hline Public administration and defence; compulsory social insurance & 24 & 19.67 \\
\hline Education & 7 & 5.69 \\
\hline Health and social welfare activities & 160 & 128.00 \\
\hline Arts, entertainment and recreation & 2 & 6.90 \\
\hline Other service activities & 1 & 3.33 \\
\hline $\begin{array}{l}\text { Activities of the household as an employer; households that produce } \\
\text { different goods and perform different services for their own needs }\end{array}$ & 0 & 0.00 \\
\hline Activities outside territorial organisations and bodies & 0 & 0.00 \\
\hline Total & 223 & 13.39 \\
\hline
\end{tabular}

Source: Register of Occupational Diseases 2020, HZJZ 


\section{Conclusion}

HZJZ's Register of Occupational Diseases takes account of all the cases of recognised occupational disease reported through the regional offices of HZZO, the Croatian Institute for Health Insurance. According to the legal provisions, confirmation and registration is performed by the SMR and, in this way, all cases of recognised occupational diseases are included on the Register.

According to SMR's analysis, the characteristics of those reporting occupational diseases (excluding those caused by asbestos) in 2020 were as follows:

- women ( $\mathrm{n}=157 ; 70.40$ per cent); men $(\mathrm{n}=66 ; 29.60$ per cent)

- workers with secondary education ( $n=137 ; 61.43$ per cent)

- the average age was 45.58 years; with the largest number of patients in the 51-60 age group $(n=74 ; 33.18$ per cent $)$,

- the average length of service in the workplace that caused the illness was 17.95 years

- workers were predominantly employed in healthcare and social welfare, largely reflecting the burden of Covid-19

- again influenced by Covid-19, the largest type of disease was among workers exposed to infectious or parasitic diseases (other than zoonoses) $(n=190 ; 84.75$ per cent); followed at a distance by statodynamic loads in the form of cumulative trauma $(n=20 ; 8.96$ per cent) and vibration $(n=4 ; 1.79$ per cent $)$.

Furthermore, in terms of the patterns of sickness absence caused by occupational disease, these are the main features:

- the largest number of days of temporary incapacity for work (sickness leave) were among workers employed in healthcare and social welfare, followed by manufacturing, and agriculture, forestry and fishing

- sickness leave lasted on average 72.64 days, with a total of 9951 sick days generated by a total of 137 occupational diseases

- most days of temporary incapacity for work were generated in the area of healthcare and social welfare (6036 days)

- the largest number of sick days occurred as a result of the impact of primarily cumulative trauma (overexertion syndromes; 4464 days); followed by vibration transmitted to hands and arms (2340 days); infectious and parasitic diseases (842 days); and, finally, allergens and skin irritants (762 days).

The increase in the number of cases of occupational disease in the health and social care sector in 2020 is largely due to the global pandemic of the SARS-CoV-2 virus and the consequent illness of health workers suffering from Covid-19. These workers return to the work system after recovery and these illnesses usually last around 15 days if there are no complications. Covid-19 was indeed the most common occupational disease in 2020 in health and social care.

The health sector is the first to be hit due to the diagnosis and treatment of patients and it could be expected that the largest number of patients would be in this activity. However, we are still unable fully to comprehend the extent of the effect of this disease which, as 2021 has continued to prove, continues to evolve. 


\section{References}

Bogadi-Šare, A (2014) 'Why the number of occupational diseases in the Republic of Croatia is low' 5. Međunarodni stručno-znanstveni skup Zaštita na radu i zaštita zdravlja Zbornik radova: Zadar, pp. 132-138 (in Croatian).

Bubaš, M, M. Milošević and D. Delić-Brjkljačić (2008) 'Occupational diseases, working ability and employment status in the working population of Croatia' Collegium Antropologicum 32(3): 677-680.

Ecimović Nemarnik, R and J. Macan (2016) 'Employment status of patients with diagnosed occupational disease: preliminary data' Sigurnost 58(3): 213-218 (in Croatian).

European Commission (2000) European Occupational Disease Statistics (EODS).

European Commission (2003) Commission Recommendation 2003/670 / EC of 19 September 2003 concerning the European schedule of occupational diseases.

Kovač, C, I. Krišto and A. Šijaković, A (2020) 'Notification of occupational diseases in the Republic of Croatia: the impact of COVID-19' SEER Journal for Labour and Social Affairs in Eastern Europe 23(1): 19-30.

Kovač, C, I. Krišto and A. Šijaković (2021) 'Bolest COVID-19 kao profesionalna bolest' Radno pravo 21(2): 39-46 (in Croatian).

\section{Legislative framework}

Hrvatski zavod za javno zdravstvo (HZJZ; Croatian Institute of Public Health) Register of Occupational Diseases for 2020 accessed 12 October 2021 at: http:// www.hzzzsr.hr/wp-content/uploads/2021/05/Registar-profesionalnih-bolestiza-2020.pdf.

Compulsory Health Insurance Act (OG 80/13, 137/13 and 98/19).

Law on the List of Occupational Diseases (OG 162/98, 107/07).

Regulation on the rights, conditions and manner of exercising compulsory health insurance rights in the event of an injury at work or an occupational disease (OG 75/14, 154/14, 79/15, 139/15, 105/16, 40/17, 66/17, 109/17, 132/17, 119/18, $41 / 19,22 / 20$ and $39 / 20)$.

National Classification of Activities 2007 (OG 58/07), comparable to the Second Revision of the International Classification of Activities, NACE 2007 (Nomenclature statistique des activités économiques dans la Communauté européenne) Rev.2.

National Classification of Occupations (OG 14/11), comparable to the International Statistical Classification of Occupations (ISCO).

Classification of the causal agents of occupational diseases, EODS. 
International Classification of Diseases and Related Health Problems - Tenth Revision, ICD-10.

Ivana Krišto is Assistant Head of the City Office of Emergency Management in the City of Zagreb, Kneza Branimira 71b, 10000 ZAGREB, Croatia. e-mail: uhs@zagre b.hr.

Cvetan Kovač is co-ordinator of the Occupational Health \& Safety Committee of Nezavisni Hrvatski Sindikati (Independent Trade Unions of Croatia), Trg Francuske Republike 9/V, 10000 ZAGREB, Croatia. e-mail: cvetan.kovac@gmail.com.

Ana Šijaković is Head of the Division for Technical Advice, Supervision and Expertise of the Croatian Institute for Health Protection and Safety at Work, Radoslava Cimermana 64a, 10020 ZAGREB, Croatia. e-mail: ana.sijakovic@gmail.com.

\section{() $(\Theta \Theta$}

BY NC ND (C) Ivana Krišto, Cvetan Kovač and Ana Šijaković 
